\title{
Menumbuhkan Kemampuan Disposisi Matematis Melalui PBL-Team Teaching
}

\author{
Anggita Maharani ${ }^{1)}$, Darhim ${ }^{2)}$, Jozua Sabandar ${ }^{3)}$, Tatang Herman ${ }^{4)}$ \\ 1) Program Studi Pendidikan Matematika, Universitas Swadaya Gunung Djati, Jl. \\ Perjuangan No. 1, Cirebon; anggi3007@yahoo.co.id \\ 2,4) Program Studi Pendidikan Matematika, Universitas Pendidikan Indonesia, Jl. Dr. \\ Setiabudi No. 229, Bandung \\ 3) Program Studi Pendidikan Matematika, IKIP Siliwangi, Jl. Terusan Jendral \\ Sudirman, Cimahi
}

\begin{abstract}
Dikirim: 30 Desember 2017; Diterima: 5 September 2018; Dipublikasikan: 25 September 2018 Cara sitasi: Maharani, A. 2018. Menumbuhkan Kemampuan Disposisi Matematis Melalui Model PBL dengan Metode Team Teaching. JNPM (Jurnal Nasional Pendidikan Matematika) Vol. 2(2), Hal.197-205.
\end{abstract}

\begin{abstract}
Abstrak. Artikel ini merupakan hasil penelitian terkait kemampuan Disposisi Matematis siswa SMK pada dua sekolah dengan level yang berbeda di Kabupaten Cirebon. Penelitian ini bertujuan untuk mengetahui interaksi antara penerapan metode $P B L$ dengan menggunakan metode team teaching terhadap kemampuan disposisi matematis siswa ditinjau dari level sekolah dan kemampuan awal matematis (KAM) siswa. Melalui metode quasi eksperimen dengan desain pre test-post test, penelitian ini melibatkan 228 siswa SMK Kelompok Teknologi \& Rekayasa. Hasil penelitian menunjukkan adanya perbedaan peningkatan rata-rata kemampuan disposisi matematis baik ditinjau dari level sekolah dan kemampuan awal matematis (KAM). Hasil penelitian juga menunjukkan adanya interaksi kemampuan disposisi matematis antara kelas konvensional, kelas PBL, dan kelas PBL-Team Teaching pada dua level sekolah berbeda ditinjau dari kemampuan awal siswa.
\end{abstract}

Kata Kunci. PBL-Team teaching, disposisi matematis

\begin{abstract}
This article is the result of research related to Mathematical Disposition abilities of vocational students in two different levels of schools in Cirebon Regency. This study aims to determine the interaction between the application of the PBL method by using the team teaching method towards students 'mathematical disposition abilities in terms of school level and students' initial mathematical abilities (KAM). Through quasi-experimental method with pre-post-test
\end{abstract}

JNPM (Jurnal Nasional Pendidikan Matematika) Vol. 2, No. 2, Hal. 197-205

p-ISSN 2549-8495, e-ISSN 2549-4937 @Prodi Pendidikan Matematika Unswagati Cirebon 
design, this study involved 228 students of the Technology \& Engineering Group Vocational School. The results showed a difference in the increase in the average ability of mathematical disposition both in terms of school level and initial mathematical ability (KAM). The results also showed the interaction between mathematical disposition abilities between conventional classes, PBL classes, and PBL-Team Teaching classes at two different school levels in terms of the students' initial abilities.

Keywords: PBL-Team teaching, mathematical disposition

\section{Pendahuluan}

Matematika merupakan mata pelajaran adaptif pada struktur kurikulum SMK. Akan tetapi motivasi belajar matematika bagi siswa SMK masih dianggap kurang dari yang diharapkan. (Maharani \& Laelasari, 2017) mengungkapkan bahwa rendahnya motivasi siswa SMK dalam mempelajari matematika karena isi yang terkandung dalam kurikulum SMK tidak memenuhi kebutuhan profesional. Berbagai anggapan negatif siswa yang mengarah pada pentingnya mempelajari matematika haruslah dihilangkan (Maharani, 2014). Disposisi matematis sebagai keinginan, kesadaran, dan dedikasi yang kuat pada diri siswa untuk belajar matematika harus ditumbuhkan dan dikembangkan.

Disposisi matematis erat hubungannya dengan kesenangan, motivasi, dan penerimaan diri siswa terhadap pembelajaran matematika yang diterimanya di dalam kelas. Itulah sebabnya kemampuan disposisi matematis selanjutnya dapat dijadikan penentu bagi keberhasilan siswa khususnya pada pelajaran matematika. Disposisi matematis meliputi sikap dan kebiasaan berpikir. Disposisi menurut (Sumarmo, 2013) meliputi keinginan, kesadaran dan dedikasi yang kuat pada diri siswa untuk belajar matematika dan melaksanakan kegiatan matematika. NCTM (Choridah, 2013) menguraikan indikator disposisi matematis yakni rasa (1) percaya diri, (2) fleksibel, (3) gigih, (4) berminat, memiliki keingintahuan dan daya cipta, (5) refleksi, (6) menghargai aplikasi matematika, dan (7) mengapresiasi peran matematika.

Hasil penelitian (Hakim, Noer, \& Gunowibowo, 2014) menunjukkan bahwa pembelajaran berbasis masalah tidak dapat meningkatkan disposisi matematis siswa. Namun jika dibandingkan dengan kelas konvensional 
seperti penelitian yang dilakukan (Sibuea, 2015) dapat diketahui bahwa peningkatan disposisi matematis siswa yang memperoleh pembelajaran berbasis masalah lebih tinggi daripada peningkatan disposisi siswa yang memperoleh pembelajaran biasa. Hasil penelitiannya juga menunjukkan bahwa tidak terdapat interaksi antara model dan kemampuan awal siswa.

Sesuai dengan tujuan pembelajaran di SMK, sangatlah penting bagi siswa SMK untuk mendapat materi pelajaran adaptif yang terkoneksi serta terintegrasi dengan materi pelajaran kejuruan. Selain itu, Standar Kompetensi Lulusan (SKL) 2013 mengamanatkan bahwa materi matematika diberikan siswa tidak hanya sekedar untuk mempelajari aspek kognitif melainkan siswa diharapkan memiliki sikap kritis, cermat, terbuka, obyektif, kreatif, punya rasa ingin tahu serta rasa menghargai dan senang matematika.

\section{Problem Based Learning (PBL)}

Problem based learning (PBL) memberikan pengalaman belajar nyata bagi siswa khususnya dalam hal menyelidiki dan memecahkan masalah (Yustianingsih, Syarifuddin, \& Yerizon, 2017). Bagi siswa SMK khususnya, PBL dapat dinilai sebagai metoda pembelajaran yang sngat tepat. PBL memfasilitasi guru untuk mengkaitkan materi pelajaran dengan situasi nyata yang yang ada di lingkungan siswa.

\section{Team Teaching}

Team teaching merupakan salah satu metode mengajar yang mampu memfasilitasi terbentuknya kemampuan interdisipliner secara terintegrasi dan terkoneksi. (Shabri, 2007) mengatakan bahwa team teaching merupakan metode mengajar sebuah mata pelajaran yang dilakukan lebih dari satu orang guru.

Team teaching dapat dilakukan oleh lebih dari dua orang guru. Metode team teaching dapat diberikan dalam bentuk semi team teaching atau team teaching penuh.

\section{Semi Team Teaching}


Metode semi team teaching memungkinkan sejumlah guru mengajar pada kelas yang berbeda atau pada kelas yang sama. Metode team teaching type semi team teaching dapat dilakukan dengan cara:

a. Sejumlah guru mengajar pada kelas yang berbeda

b. Sejumlah guru mengajar pada kelas yang sama (bergantian)

\section{Team Teaching Penuh}

Metode team teaching type team teaching penuh dapat dilakukan dengan cara:

a. Sejumlah guru mengajar pada kelas yang sama (1 orang guru mengajar, yang lainnya membimbing)

b. Sejumlah guru mengajar pada kelas yang sama (memberikan materi secara bergantian)

c. Sejumlah guru mengajar pada kelas yang sama (1 orang guru senior mengajar memberikan materi inti, selebuhnya pengajaran dilakukan oleh guru yang lain)

PBL-Team Teaching merupakan pengembangan dari model PBL dimana pengajarannya dilakukan secara tim (team teaching). Metode ini sangatlah tepat untuk diberikan pada siswa SMK dimana siswa SMK memiliki karakteristik dan kekhasan dibandingkan siswa menengah umum. Dalam pelaksanaannya, PBL-Team Teaching mengacu pada sintax PBL yakni orientasi masalah, mengorganisasi siswa, membantu investigasi mandiri, mengembangkan \& mempresentasikan hasil, menganalisis \& mengevaluasi.

Implementasi $P B L$ setidaknya melibatkan tiga komponen yakni siswa sebagai pembelajar, guru sebagai tutor, dan masalah sebagai konteks (Setiyani, Maharani, \& Ferdianto, 2017). Siswa SMK sangat dekat dengan masalah yang bersifat ill-defined, messy, kompleks, menisyaratkan berpikir kritis dan pemecahan masalah terutama yang berhubungan dengan profesi kejuruannya. Itulah sebabnya, $P B L$ menjadi metode yang utama digunakan dalam pembelajaran di SMK.

Untuk mendapatkan kecakapan kejuruan siswa dengan sesuai dengan tujuan SMK, sangatlah penting bagi pembelajaran matematika untuk diintegrasikan dengan mata pelajaran produktif sebagai mata pelajaran 
keahlian siswa SMK. Agar pembelajaran matematika di SMK sejalan dengan kebutuhan siswa SMK, maka konteks yang dipilih untuk mata pelajaran matematika SMK adalah konteks yang berkaitan dengan dengan bidang kejuruannya. Melalui PBL-Team Teaching, pembelajaran matematika tersampaikan secara terintegratif dengan materi kejuruan.

PBL-Team Teaching pada pembelajaran matematika untuk siswa SMK, adalah metode pembelajaran matematika yang melibatkan guru matematika dan guru kejuruan sebagai sumber belajar. Menurut (Abdullah, 2012), sumber belajar adalah semua sumber seperti pesan, orang, bahan, alat, teknik, dan latar yang dimanfaatkan peserta didik sebagai sumber untuk kegiatan belajar dan dapat meningkatkan kualitas belajarnya.

\section{Metodologi Penelitian}

Penelitian ini menggunakan metode quasi eksperimen yang melibatkan dua SMK dengan level berbeda. Desain penelitiannya dapat digambarkan sebagai berikut:

$\begin{array}{llll}\text { A } & \mathrm{O} & \mathrm{X} 1 & \mathrm{O} \\ \mathrm{A} & \mathrm{O} & \mathrm{X} 2 & \mathrm{O} \\ \mathrm{A} & \mathrm{O} & & \mathrm{O}\end{array}$

(Ruseffendi, 2005)

Keterangan:

$\mathrm{O}=$ Disposisi Matematis

X1 $=$ Model PBL

X2 = Model PBL dengan metode team teaching

Sampel penelitian ditentukan dengan menggunakan teknik stratified sampling (teknik strata). Dari sejumlah SMK se-Kabupaten Cirebon yang memiliki bidang keahlian Teknologi \& Rekayasa, dikelompokkan menjadi 3 level sekolah yaitu level tinggi, sedang, dan rendah yang didasarkan pada kondisi obyektif perolehan jumlah rata-rata nilai ujian nasional (UN), nilai akreditasi sekolah, dan Standar Pencapaian Minimal (SPM) sekolah. Selanjutnya dipilih 1 sekolah level level sedang dan 1 sekolah level rendah. Dari masing-masing level sekolah, dipilih tiga kelas XI secara acak untuk dijadikan sebagai kelompok kontrol, eksperimen 1 (menggunakan model $P B L$ ), dan kelompok eksperimen 2 (menggunakan model PBL-Team Teaching).

JNPM (Jurnal Nasional Pendidikan Matematika) Vol. 2, No. 2, Hal. 197-205 p-ISSN 2549-8495, e-ISSN 2549-4937 CProdi Pendidikan Matematika Unswagati Cirebon 
Tabel 1. Sampel Penelitian Berdasarkan Level Sekolah

\begin{tabular}{ccc}
\hline Level Sekolah & Kelompok & Ukuran Sampel \\
\hline \multirow{3}{*}{ Sedang } & Kontrol & 42 \\
& Eksperimen 1 & 43 \\
& Eksperimen 2 & 43 \\
\multirow{3}{*}{ Rendah } & Kontrol & 35 \\
& Eksperimen 1 & 37 \\
& Eksperimen 2 & 28 \\
\hline
\end{tabular}

Dari masing-masing kelompok, siswa kemudian dikelompokkan lagi berdasarkan Kemampuan Awal Matematika (KAM) nya yaknik siswa dengan KAM tinggi, sedang, dan rendah.

Instrumen yang digunakan berupa angket berisikan skala disposisi matematis. Sebelum dan setelah penelitian, siswa diberi angket disposisi Matematis. Skala disposisi matematis yang digunakan memuat 7 indikator yakni (1) percaya diri, (2) fleksibel, (3) gigih, (4) berminat, memiliki keingintahuan dan daya cipta, (5) refleksi, (6) menghargai aplikasi matematika, dan (7) mengapresiasi peran matematika menurut NCTM (Choridah, 2013). Skala disposisi yang digunakan terdiri dari 30 item dengan empat pilihan jawaban yaitu Sangat Setuju (SS), Setuju (S), Tidak Setuju (TS), dan Sangat Tidak Setuju (STS) (Clason \& Dormody, 1994) (Boone \& Boone, 2012). Sebelum angket digunakan, angket divalidasi untuk mengukur validitas isi. Aspek yang diukur meliputi kesesuaian pernyataan dengan aspek disposisi, kesesuaian dengan tingkat perkembangan siswa menengah atas (usia 15 - 19 tahun), kejelasan soal ditinjau dari segi bahasa atau redaksional, dan kejelasan sajian atau penampilan. Sebelum skala disposisi digunakan, terlebih dahulu diujicobakan pada 43 siswa yang bukan kelompok sampel untuk menguji keterbacaan. Perhitungan skor item disposisi selanjutnya dilakukan dengan program Microsoft Office Excel 2007.

\section{Hasil dan Pembahasan}

Untuk mengetahui bagaimana kemampuan disposisi matematis, siswa diberi angket di awal dan di akhir pertemuan pembelajaran berupa skala disposisi matematis. Analisis kemudian dilakukan berdasarkan level sekolah, kemampuan awal matematis (KAM), dan berdasarkan penggunaan model 
pembelajaran. Untuk selanjutnya, siswa pada kelas yang menggunakan model konvensional disebut sebagai kelompok kontrol, siswa yang menggunakan model $P B L$ disebut sebagai kelompok eksperimen I, dan siswa yang menggunakan model PBL-Team Teaching disebut sebagai kelompok eksperimen II.

Hasil analisis berupa peningkatan skor respon siswa terhadap angket disposisi matematis yang diberikan, ditunjukan pada tabel berikut:

Tabel 2. Rata-rata skor peningkatan Disposisi

\begin{tabular}{|c|c|c|c|}
\hline \multirow[t]{2}{*}{ Level Sekolah } & \multicolumn{2}{|c|}{ Kelompok } & \multirow{2}{*}{$\begin{array}{c}\text { Mean } \\
-5,4800\end{array}$} \\
\hline & Kontrol & KAM Rendah & \\
\hline \multirow{8}{*}{ Rendah } & & KAM Sedang & 2,5600 \\
\hline & & KAM Tinggi & $-1,1200$ \\
\hline & Eksperimen 1 & KAM Rendah & $-9,500$ \\
\hline & & KAM Sedang & 1,6100 \\
\hline & & KAM Tinggi & $-1,6900$ \\
\hline & Eksperimen 2 & KAM Rendah & 3,0400 \\
\hline & & KAM Sedang & 3,0000 \\
\hline & & KAM Tinggi & 4,3400 \\
\hline \multirow{9}{*}{ Sedang } & Kontrol & KAM Rendah & 2,8700 \\
\hline & & KAM Sedang & 3,5700 \\
\hline & & KAM Tinggi & 3,1800 \\
\hline & Eksperimen 1 & KAM Rendah & 2,9200 \\
\hline & & KAM Sedang & 2,3600 \\
\hline & & KAM Tinggi & 3,1200 \\
\hline & Eksperimen 2 & KAM Rendah & 3,8900 \\
\hline & & KAM Sedang & 3,7800 \\
\hline & & KAM Tinggi & 3,2400 \\
\hline
\end{tabular}

Berdasarkan tabel 2, dapat diketahui bahwa rerata peningkatan disposisi matematis paling tinggi untuk level sekolah rendah terdapat pada kelompok eksperimen 1 (kelompok dengan $P B L$ ). Sedangkan rerata peningkatan tertinggi pada level sekolah sedang terdapat pada kelompok eksperimen 2 (kelompok dengan PBL-Team Teaching). Jika dilihat dengan gambar, peningkatan (gain) berdasarkan level sekolah tergambar sebagai berikut: 


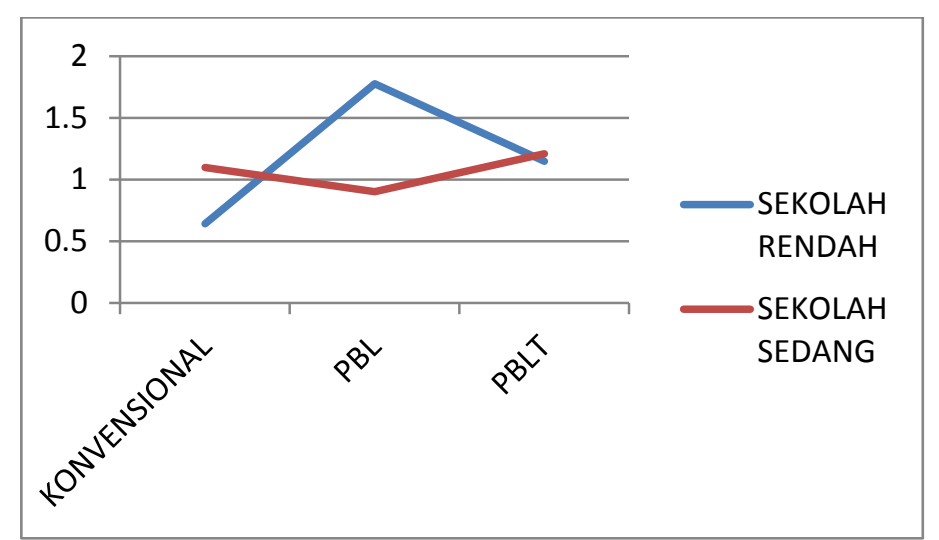

Gambar 1. Rerata Peningkatan (Gain) Disposisi Matematis berdasarkan level sekolah

Selanjutnya hasil analisis menunjukkan adanya interaksi kemampuan disposisi matematis berdasarkan level sekolah dan penggunaan model. Namun uji statistik menggambarkan tidak adanya perbedaan peningkatan disposisi matematis jika ditinjau dari Kemampuan Awal Matematika (KAM).

\section{Simpulan dan Saran}

Beberapa kesimpulan yang dapat diambil dari penelitian ini adalah diketahui bahwa: (1) terdapat perbedaan peningkatan kemampuan disposisi matematis dengan level sekolah; (2) terdapat perbedaan peningkatan kemampuan disposisi dengan model Konvensional, $P B L$, dan PBL-Team Teaching; (3) tidak ada perbedaan peningkatan kemampuan disposisi matematis jika ditinjau dari Kemampuan Awal Matematika (KAM)

Secara keseluruhan, dapat diketahui bahwa ada interaksi yang signifika antara kemampuan disposisi matematis berdasarkan level sekolah dan penggunaan model pembelajaran dalam hal ini PBL dan PBL-Team Teaching.

\section{Daftar Pustaka}

Abdullah, R. (2012). Pembelajaran berbasis pemanfaatan sumber belajar. Jurnal Ilmiah Didaktika, 12(2).

Boone, H. N., \& Boone, D. A. (2012). Analyzing likert data. Journal of Extension, 50(2), 1-5.

Choridah, D. T. (2013). Peran Pembelajaran Berbasis Masalah untuk Meningkatkan Kemampuan Komunikasi dan Berpikir Kreatif serta Disposisi Matematis Siswa SMA. Infinity Journal, 2(2), 194-202.

Clason, D. L., \& Dormody, T. J. (1994). Analyzing data measured by individual Likert-type items. Journal of Agricultural Education, 35, 4. 
Hakim, S., Noer, S. H., \& Gunowibowo, P. (2014). Penerapan Pembelajaran Berbasis Masalah Untuk Meningkatkan Kemampuan Berpikir Kritis dan Disposisi Matematis. Jurnal Pendidikan Matematika Universitas Lampung: Universitas Lampung.

Maharani, A. (2014). Psikologi Pembelajaran Matematika Di Smk Untuk Mendukung Implementasi Kurikulum 2013. Euclid, 1(2).

Maharani, A., \& Laelasari, L. (2017). Experimentation Of Spices Learning Strategies With The Method Of Problem Based Learning (Pbl) To Build Motivation And The Ability To Think Logically For Vocational School Students. Infinity Journal, 6(2), 149-156.

Ruseffendi, E. T. (2005). Dasar-dasar penelitian pendidikan dan bidang noneksakta lainnya. Bandung: Tarsito.

Setiyani, S., Maharani, A., \& Ferdianto, F. (2017). Pengaruh Aktivitas Belajar Mahasiswa Dengan Model Problem Based Learning Terhadap Kemampuan Penalaran Matematis Pada Mata Kuliah Kalkulus Iii. Repository FKIP Unswagati.

Shabri, A. (2007). Strategi belajar mengajar micro teaching. Jakarta: Quantum Teaching.

Sibuea, M. F. L. (2015). Peningkatan Kemampuan Komunikasi Dan Disposisi Matematis Siswa Smk Tamansiswa Sukadamai Kabupaten Asahan Melalui Model Pembelajaran Berbasis Masalah. Unimed.

Sumarmo, U. (2013). Kumpulan makalah berpikir dan disposisi matematik serta pembelajarannya. Bandung: Fakultas Pendidikan Matematika Dan Ilmu Pengetahuan Alam Universitas Pendidikan Indonesia Bandung.

Yustianingsih, R., Syarifuddin, H., \& Yerizon, Y. (2017). Pengembangan Perangkat Pembelajaran Matematika Berbasis Problem Based Learning (PBL) untuk Meningkatkan Kemampuan Pemecahan Masalah Peserta Didik Kelas VIII. JNPM (Jurnal Nasional Pendidikan Matematika), 1(2), 258-274.

JNPM (Jurnal Nasional Pendidikan Matematika) Vol. 2, No. 2, Hal. 197-205 p-ISSN 2549-8495, e-ISSN 2549-4937 @Prodi Pendidikan Matematika Unswagati Cirebon 